\title{
Kansansivistyksen kadottaminen
}

\author{
Seppo Niemelä
}

On kiinnostava kysymys, miten ja mihin ajatus itsenäisestä kansansivistyksestä Suomessa katosi. Osin kyseessä oli varmastikin kansansivistystradition eräiden perimmäisten ajatusten kertakaikkinen vanheneminen. Jotakin oleellista yhteisöllistä menetettiin, kun vapaa kansansivistystyö muuttui vapaaksi sivistystyöksi ja toiminnan yhteys kansalaisyhteiskuntaan ja demokratiaan heikkeni, kirjoittaa Seppo Niemelä analysoidessaan kansansivistyksen keskeisiä sanoja: kansa, sivistys, sivistystyö ja vapaus.

Pohjoismainen vapaa kansansivistystyö eli monipolvisen mutta vahvan kehityskaaren 1840luvun alustaan 1990-luvun lamaan asti. Se selvisi Suomessa hyvin vuoden 1970 aikuiskoulutuskomiteasta, jossa niin harrastustavoitteinen kuin yhteiskunnallinenkin kasvatus löysivät paikkansa osana uutta kokonaisuutta. Määrällinen kasvu jatkui ripeänä (Toiviainen 1998, 16). Silti käsitys vapaan kansansivistystyön itsenäisestä tehtävästä alkoi 1960-luvulla heikentyä. Ilmiö tunnetaan kaikissa pohjoismaissa. Sivistys ja humanismi muuttuivat, kuten Ove Korsgaard (1997, 442) sanoo, vanhanaikaisiksi ja epäoleellisiksi.

Ensin Tanskassa ja sitten Ruotsissa käytiin 1980luvulla myrskyisiä keskusteluja siitä, perustuuko kansansivistyksen instituutioiden toiminta itsenäiseen kansansivistyksen ideaan vai pitäisikö niitä erityisinä työmuotoina suunnata koulujärjestelmän aukkojen paikkaajaksi. Molemmissa maissa itsenäistä tehtävää puolustanut kanta voitti. Se johti mm. kansansivistyksen omiin lakeihin ja uusiin työn tukemisen tapoihin. Ruotsissa valtion ohjauksen ja kansansivistyksen vapauden välinen ongelma ratkaistiin perustamalla "kentän ja valtion väliin" kansansivistysneuvosto. Se jakaa valtion kansansivistykselle osoittamat rahat, mutta vastaa toiminnan tuloksellisuudesta valtiolle. Neuvoston käynnistämä mittava arviointityö on merkittävästi selkeyttänyt ja vahvistanut kansansivistyksen asemaa (ks. esim. FBR, 1998).

Suomessa vastaava kriisi tuli myöhemmin. Vahva ennusmerkki oli alan (toistaiseksi) viimeisen professorin Aulis Alasen resignoitunut toteamus (1992, 41), jonka mukaan "tuskin on löydettävissä perusteita sille, että vapaa sivistystyö eroaa vuosikymmenen lopussa muusta aikuiskasvatusjärjestelmästä”. Yhtenä taustana voi olettaa olleen hänen oma järjestöllistä sivistystyötä koskenut tutkimuksensa (1986) ja Pauli Siljanderin (1982) kansanopistoa koskenut tutkimus. Kumpikaan ei enää löytänyt erityisen itsenäistä kansansivistyksen ideaa. Alasen ennustus oli lähellä toteutumistaan, kun ns. Nummisen komitea 1996 ehdotti, että Suomessa luovutaan omista vapaan sivistystyön laeista. Vapaa sivistystyö sai kuitenkin eräänlaisen jatkoajan poliitikkojen päätöksellä. ${ }^{1}$ 
On kiinnostava kysymys, miten ja mihin ajatus itsenäisestä kansansivistyksestä Suomessa katosi. Osin kyseessä oli varmastikin kansansivistystradition eräiden perimmäisten ajatusten kertakaikkinen vanheneminen. Me tuskin saavutamme enää J. G. von Herderin uljasta visiota siitä, miten Kaitselmus johtaa universumiaan omia kehityspolkujaan kulkevien kansakuntien kautta ja miten yksityinen ihminen löytää paikkansa tässä luomistyössä tutkimalla oman kansansa kieltä ja historiaa. Tällainen vakaumus siivitti Suomen kansansivistyksen isää, J. V. Snellmania (ks. esim. 1991, 73- ) ja N. Fr. S. Grundtvigia (Korsdgaard 1997,173). Sen kaikuja tapaamme vielä nuorisoseuramies Santeri Alkion tuskaisissa päiväkirjamerkinnöissä kansalaissodan päiviltä: "Olen rakentanut koko elinaikani sen ihanteellisen uskon pohjalle, että kansa nousee ja sivistys jumalan ikuisten luonnonlakien mukaan toteuttamaan itsensä” (sit. Kuisma ym., 1983, 23).

Silti on hyödyllistä tutkia, syntyikö kansansivistyksen pohjoismaisessa traditiossa myös sellaista, joka on edelleen arvokasta ja johon nykypäivän tulisi saada uudestaan yhteys. Seuraavassa siihen pyritään selvittämällä, mitä vapaan kansansivistystyön keskeisille käsitteille kansa, sivistys, sivistystyö ja sen vapaus tapahtui 1960-luvulta alkaen. Peilaan Suomen kehitystä traditioltaan vahvempiin Tanskaan ja Ruotsiin keskeisenä kiinnekohtana Ove Korsgaardin tärkeä historiateos (1997) ja asiaa sivuava ruotsalainen keskustelu. Sosiaalisesta pääomasta käyty keskustelu auttaa tulkitsemaan yhteisöllisyyden merkitystä.

\section{KANSA}

K ansa katosi vapaasta kansansivistystyöstä 960-luvulla Suomessa kokonaan. Sanaa lakattiin vähin äänin käyttämästä. Uudeksi nimeksi vakiintui vapaa sivistystyö. (Tuomisto, 1992, 40). Kansa jäi jäänteeksi joihinkin nimityksiin (kansanopisto, Kansanvalistusseura, Svenska folkskolans vänner, tavallaan kansalaisopisto). Muutos helpotti sivistystyön yksilöllistymistä. Sivistyksen henkilökohtaistumisen prosessi tosin toteutui kaikissa pohjoismaissa; Korsgaard (1997, 16) nimittää viime vuosikymmeniä Tanskassa "persoonallisen valistuksen" kaudeksi. Kiinnos-

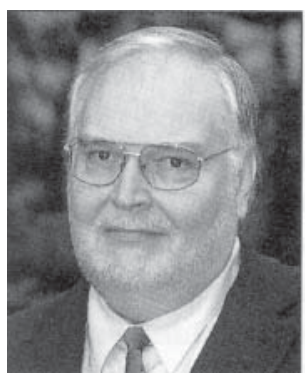

Seppo Niemelä

tavaa on, että kokonaan kansa katosi kuitenkin vain Suomessa. Sitä, mikä on kansansivistyksen kansa, on muissa Pohjoismaissa kysytty kansansivistyksestä tai kansanvalistuksesta käytävässä keskustelussa aina meidän päiviimme. Kansa on ollut osa toiminnan identiteettiä.

Korsgaardin $(1999,49)$ mukaan kansaa voidaan käyttää ainakin kolmessa merkityksessä. Kansalla voidaan tarkoittaa "rahvasta" yläluokan vastakohtana. Sillä voidaan tarkoittaa "demosta", kansaa itse itseään suvereenisti hallitsevana subjektina (esim. kansanvalta, kansanäänestys). Niinikään kansa voi tarkoittaa "etnosta", kansaa kulttuurisena identiteettinä (esim. kansanlaulu, kansankulttuuri). Pohjoismaisen kansansivistyksen suuri linja on ollut sen kehitysprosessin tukeminen, jossa alamaisesta rahvaasta on tullut itse itseään hallitseva kansa, tanskalaisittain "fra almue til folk". Prosessia tuki kansallisen identiteetin vahvistaminen kansankulttuurin avulla, minkä aloitti Herder Volkslied-kirjallaan. Myös Suomessakin se koettiin tärkeäksi. Samassa tahdissa syntyvä ja vahvistuva demokraattinen kansallisvaltio loi toiminnalle puitteen. Käsite-erottelu on hyödyllinen moniin tarkoituksiin, vaikkapa kun yritetään ymmärtää pohjoismaiden vaikeuksia sopeutua EUjäsenyyteen. Nyt demos on muuttumassa osin eurooppalaiseksi, mikä edellyttää sen vahvojen etnos-siteiden höllentämistä samaan tapaan kun uskonnon ja politiikan side aikanaan heikkeni. Silti kansojen kulttuurinen identiteetti saattaa olla hyvinkin tärkeä myös itseään kulttuurisena mosaiikkina rakantavassa Euroopassa.

Keskeinen osa "rahvaasta kansaksi" -prosessia oli se vapaan (NGO), vapaaehtoisen ja voittoa tuot- 
tamattoman (non profit) yhdistyselämän synty, joka loi yhteiskuntaan monimuotoisen toimintojen kudelman uskonnosta urheiluun, sosiaalisesta avusta osuustoimintaan ja harrastuksista ammatilliseen ja poliittiseen järjestäytymiseen. Korsgaard tekee (1997, 120-) kiinnostavan havainnon kysyessään, miksi tätä pohjoismaissakin niin voimakasta kolmatta sektoria on vasta viime vuosina alettu nimittää kansalaisyhteiskunnaksi. Vastaus on, ettei siihen aiemmin ole ollut tarvetta. Vaikka käsitteiden kansa ja kansalaisyhteiskunta merkitys ei olekaan täysin päällekkäinen, on sanaa kansa (vrt. esim. kansanliike) saksalais-pohjoismaisella kulttuurialueella käytetty samassa merkityksessä kuin angloamerikkalaista kansalaisyhteiskuntaa. Kansansivistys toimi kansan, toisin sanoen kansanliikkeiden ja koko kansalaisyhteiskunnan kouluna, yhdistyksissä tapahtuvan opintotoiminnan organisoijana ja kansallisvaltion sisäisen demokratian vahvistajana.

Jotakin oleellista yhteisöllistä menetettiin, kun vapaa kansansivistystyö muuttui vapaaksi sivistystyöksi ja toiminnan yhteys kansalaisyhteiskuntaan ja demokratiaan heikkeni. Vaatisi oman aatehistoriallisen tutkimuksensa selvittää, miksi kansasta niin helposti Suomessa luovuttiin. Jäikö "rahvaasta kansaksi" -prosessi Suomessa sillä tavoin kesken, että kansaan jäi koonnotaatio alaluokasta eikä se enää tuntunut sopivan demokratisoituvaan yhteiskuntaan? Eivätkö suomalaiset kokeneet olevansa itse itseään hallitseva kansa? Oliko kansandemokratia sotien jälkeisessä Suomessa sillä tavoin latautunut käsite, että se leimasi herkän sivistysväen mielessä myös ilmaisua kansansivistys? Vai kuuluuko Suomi sittenkin enemmän saksalaiseen kuin pohjoismaiseen kulttuuripiiriin; edellisessä kansakunnan ydin on valtio, jälkimmäisessä kansa?² Joka tapauksessa kansansivistyksen kansasta ei Suomessa ole käyty keskustelua vuosikymmeniin ja sen kansasta määräytyvä tehtävä on jäänyt varjoksi siitä, mikä olisi ollut mahdollista.

\section{SIVISTYS}

ivistys jäi sanana elämään, mutta käsitteenä se Sai riisua oleellisen sisältönsä. Lähes dramaat- tisesti tämä havainnollistui vuoden 1960 yleisessä kansansivistyskokouksessa, jossa kansalaisuus oli vielä aktiivisen mielenkiinnon kohteena. Vapaan sivistystyön jo silloin vahva mies, sen määrällisen kasvun keskeinen arkkitehti ja aikansa modernin koulutuksen saanut Kosti Huuhka otti kokouksessa henkisiä ohjia käsiinsä. Huuhkan (1960, 15) mukaan "saksan Bildung on eräs epämääräisimmistä kulttuurikäsitteistä”. Intohimoisesti sitä on yritetty ja yritetään edelleen selittää. Käsitteen ongelma on sen arvosisältö, josta syystä "se ei ole erityisen käyttökelpoinen empiirisen todellisuuden kuvaamiseen." Huuhka ilmaisee hyvin sen, miten empiirinen sukupolvi siirsi sivistyksen vuosikymmeniksi sivuun aktiivisen mielenkiinnon kohteista. Heiluri oli hypähtänyt toiseen ääripäähänsä kansakunnassa, jonka syntykin oli perimmiltään sivistysprosessi.

Korsgaardin $(1997,127)$ mukaan Herder oli ensimmäinen, joka käytti käsitteitä Bildung ja sen tarkoitus humaniteetti jokseenkin nykymerkityksessä. Snellman nosti ne kansakunnan peruskiviksi Suomessa; omakielisiksi vastineiksi vakiintuivat sivistys ja ihmisyys. Sivistysajatuksen edelleen kestävä ydin on siinä, että ihminen kehittää kasvatuksen, harjaantumisen ja itsekasvatuksen avulla esiin itsessään luontaisesti olevia potentiaaleja. Havainto vastaa arkikokemusta; lapsessa ja aikuisessakin voi piillä loistava muusikko, matemaatikko tai vaikkapa yhteisöllisyyden luoja, mutta sisäiset mahdollisuudet realisoituvat vain sopivissa ympäristöoloissa ja kasvatuksen tukemana. Mitä nämä potentiaalit perimmiltään ovat ja miten niitä harjaannutetaan, on sivistystyön keskeinen kysymys. Intohimoiset selitysyritykset ovat nostaneet myös viime vuosina esiin kiinnostavia näkökantoja. Seuraavat kaksi käyköön esimerkiksi.

Ruotsalaiset käänsivät saksan termin suoraan omalle kielelleen. Bernt Gustavssonin mukaan (1996, 16) käsite bildning voidaan yhdistää kahteen keskenään jännitteessä olevaan asiaan. Toinen on bild tai förebild, kasvun ja kasvatuksen tavoitteen antava esikuva, joka voi olla vaikkapa jokin ideologia tai opetussuunnitelma. Toinen on bilda (skapa, forma), joka viittaa ihmisen omasta persoonallisuudesta kumpuavaan aktiivi- 
seen luomiseen. Kansansivistys korostaa jälkimmäistä, prosessinomaista uutta luovaa ja osanottajien ohjaamaa toimintaa. Sen merkitys kasvaa nopeasti muuttuvana nykyaikana, jossa valmiita esikuvia ei yksinkertaisesti ole ja jossa ihmiset ovat tavallaan jatkuvassa ongelmanratkaisutilanteessa. Gustavsson on tehnyt myös hermeneuttisen filosofian pohjalta kiinnostavia sivistyskäsitteen tulkintoja.

Tanska ja Norja käyttävät edelleen nimitystä kansanvalistus, mutta nykykäytössä käsitteet valistus ja sivistys ovat rinnakkaisia. Korsgaard kysyy (1997, 137), mistä valistuksen valo tulee? Historian kuluessa kysymykseen on vastattu eri tavoin. Valo voi tulla "ylhäältä" annettuna ilmoituksena (Luther) tai muutoin auktoriteeteilta, "ulkoa" ympäristöstä, jota ihminen heijastaa peilin tavoin (Locke), "sisältä" ihmisessä olevasta järjestä (Kant) tai "alhaalta" kansasta tai yhteisöstä (Herder, Grundtvig). "Ylhäältä/alhaalta"-linja voidaan yhdistää vertikaaliseksi ja "ulkoa/sisältä" horisontaaliseksi käsitykseksi. Nämä ovat olleet keskinäisessä jännitteessä valistuksen ajasta romantiikkaan ja nykypäivään. Kansansivistys syntyi vertikaalisen linjan herätteistä, mutta on muuttunut lähes yksinomaan horisontaaliseksi.

(Yleis)sivistyksellä on välinearvonsa ja tavallisesti sitä perustellaan ammattikasvatuksen kautta tai sen pohjanluojana. (Ammattikasvatusta perustellaan harvemmin sillä ilmeisellä seikalla, että hyvä ammatti luo osaltaan pohjan sivistyspyrinnöille.) Ehkä tärkein sivistyksen pohdinnan tulos on se, että sivistys on myös itseisarvo. Se, että ihminen voi toteuttaa sisäiset potentiaalinsa niiden täyteen mittaan, on päämäärä sinänsä ja osa hyvää elämää. Näkökannalla on Suomessa eräiden filosofien ohella harvoja puolustajia, yhtenä esimerkkinään Erik Allardt. Tällaisessa ilmapiirissä sivistystyöllä on ollut ahdas elintila.

\section{SIVISTYSTYÖ}

$\mathrm{T}$ ärkein vanhahtavaan maineeseen ajautuneelle vapaalle sivistystyölle 60-luvulta lähtien annettu lääke oli se, että toiminnasta haluttiin tehdä vakavamielistä opiskelua. Kehittäjien keskeinen korostus on ollut toiminnan opinnollisuus. Tie- topohjaa aikakauden pyrkimykselle loi Aulis Alasen väitöskirja (1969), jossa hän jakoi opintokerhon tavoitteet kahteen pääryhmään: opinnollisiin ja viihdytyshakuisiin. Arto Leistevuo kuvaa aikuisopiskelun sosiaalisia motiiveja kuvaavassa tutkimuksessaan $(1998,25)$, miten tavoitesuuntauksiin ilmestyi luokka "viihde-sosiaaliset kontaktit". Viihteeksi koetusta sosiaalisuudesta tuli kokonaiselle sivistystyöntekijöiden sukupolvelle poisjuurittava ongelma, kun tavoitteena oli tavoitteellisesti opiskeleva yksilö. Leistevuon tutkimuksen mukaan oppijat ovat kuitenkin itsepintaisesti pitäneet sosiaalista aspektia tärkeänä. Hän ei kyseenalaista kysymyksenasettelua, mutta on myöhemmin päätynyt esittämään, että vapaalle sivistystyölle on sallittava viihtymistavoite (!)

Sosiaalinen aspekti on kuitenkin ollut toiminnan alusta asti kansansivistyksen ydinkysymys ja kaikkea muuta kuin viihdettä. Siljander (1982, 68-70) kuvaa, miten Grundtvigin "koulu elämää varten" -ohjelman keskeinen didaktinen peruskäsite oli elävä vuorovaikutus, jolle herätteen antoi elävä sana (mm. kuolleen ja tentittävän kirjatiedon vastakohtana). Vuorovaikutuksella oli monia ilmenemismuotoja opiskelijan ja opettajan keskinäisestä dialogista vuorovaikutukseen, jota toteutui elämäntilanteen ja -käytännön sekä toisaalta historiallisen kokemuksen kanssa. Vuorovaikutusta tarvittiin myös yhteiskuntaryhmien välillä. Vuorovaikutuksen perusta oli elävien ihmisten yhteisö, kansanopistossa internaatti. Ajatuksista kehittyi erityinen internaattipedagogiikka. Sen tavoitteena ei ollut niinkään tämä tai tuo oppimäärä, vaan elämänvalistus, kyky ymmärtää omaa elämäänsä. Elämänvalistus syntyi prosessissa, jossa persoonallinen kokemus (følelse) ja tietäminen tai ymmärrys (forstand) olivat keskinäisessä dialogissa. Kehitys ja kasvu edellyttävät Siljanderin tulkinnan mukaan "sosiaalista vuorovaikutusta, kokemuksen yhteyttä". Kuvaavaa on, ettei Grundtvig ollut "opinnollisten" kokeiden, todistusten tai tutkintojen kannattaja, koska muisti- ja tutkintokoneet olivat aina hengelle vieraita (Bergstedt, 1998, 179). Sen sijaan hän muiden sivistystyön klassikoiden tavoin korosti oppimaan oppimisen merkitystä. Tanskalainen ja Suomeenkin vaikuttanut kansan- 
opisto oli näiden periaatteiden sovellus ja se tuntuu nykyongelmien taustaa vasten yhtä tarpeelliselta kuin 150 vuotta sitten.

Kansansivistyksen toinen oma työmuoto internaattipedagogiikan rinnalla on sata vuotta sitten yhdysvaltalaisista virikkeistä Ruotsissa kehitetty innovaatio, opintopiiri tai -kerho, jota on käytetty sekä itsenäisenä että kansanliikkeiden työmuotona. Siinä on yhteisiä piirteitä internaattipedagogiikan kanssa siitäkin huolimatta, ettei Grundtvig ole ollut erityisen harrastuksen kohteena Ruotsissa. Opintopiirissä ryhmä ihmisiä kokoontuu oman elämänkokemuksensa pohjalta luomaan uutta tietoa ja harjaantumaan sosiaalisesti. Tore Johansson (1990, 118, 112-114) tiivistää ruotsalaisen tutkimuksen pohjalta opintokerhon oleelliset periaatteet seuraavaan tapaan. Työmuoto rakentuu samanarvoisten osanottajien dialogiin ilman keskinäistä kilpailua, suoritustarvetta, todistuksia ja hierarkiaa. Keskeinen pedagoginen periaate oli yhteenkuuluvuus ja yhteisöllisyys. Osanottajien omat tarpeet ohjasivat oppimista, jonka lähtökohtana oli oma tiedon taso. Opintojen katsottiin antavan tietojen ja taitojen ohella argumentoinnin, keskustelun, toisten huomioonottamisen ja vastuunjaon valmiuksia. Työmuoto harjaannuttaa demokraattista ajattelua ja toimintaa. Vaikka oppiminen edellyttää aina vaivannäköä, toveripiirin yhteistyö tuo mukanaan "viihtymistä, iloa ja virkistystä", kuten ABF:n monivuotinen opintojohtaja Gunnar Hirdman sittemmin Suomessa kohtalokkaaksi käyneen piirteen ilmaisi.

Yhteisöllinen ja dialoginen oppiminen voi olla tehokas keino tietojen ja taitojen omaksumiseen, mutta kansansivistyksen omat työmuodot tähtäsivät laajemmalle. ${ }^{3}$ Henkisen pääoman ohella ne kehittivät yhdessä kansalaisyhteiskunnan kanssa jotakin, jota viime vuosina on alettu kutsua sosiaaliseksi pääomaksi. Robert D. Putnamin (2000, 19) mukaan henkinen (human) pääoma liittyy yksilön ominaisuuksiin, kun taas sosiaalinen pääoma viittaa "yksilöiden keskinäisiin yhteyksiin - sosiaalisiin verkostoihin ja niistä nouseviin vastavuoroisuutta ja luottamuksenarvoisuutta koskeviin normeihin". Näillä ja erityisesti luottamuksella on tärkeä merkitys koko yhteiskunnal- le, aina valtion ja markkinoiden toimintakykyä myöten.

Kansalaisyhteiskuntaa on pidetty sosiaalisen pääoman keskeisenä generaattorina ja samalla yhtenä demokratian edellytyksenä (Putnam 1993, 183). Kansansivistyksen kadottaminen on kiinnostavalla tavalla rinnakkainen Putnamin (2000) kuvaaman amerikkalaisen yhteisöllisyyden romahtamisen kanssa. Edwards (1999) tiivistää Maailmanpankissa muotoutuneen mutta myös pohjoismaiselle kansansivistykselle avaria näköaloja avaavan käsityksensä seuraavasti: Sosiaalinen pääoma voidaan ymmärtää kumulatiiviseksi kapasiteetiksi työskennellä yhdessä yhteisten päämäärien hyväksi ja kansalaisyhteiskunta tilaksi, jossa nämä päämäärät muotoillaan ja jossa niistä keskustellaan; päämäärien toteutuksessa tarvitaan myös valtiota ja markkinoita, mutta ne ovat todellisen kansalaisyhteiskunnan palvelijoita, ei sen herroja.

Kansansivistyksen yhteisöllinen perintö eli ja elää monissakin vapaan sivistystyön instituutioissa; Sten-Erik Fagerlund (1984, 151-166) esittää hienolla tavalla yhden esimerkin sen toteutuksesta vielä 1980-luvun ahvenanmaalaisessa todellisuudessa. Perintö vaikutti oman muistikuvani mukaan ryhmätyön runsaaseen käyttöön, osanottajien oman panoksen huomioonottavaan lyhytkurssipedagogiikkaan ja projektityöhön. Siljander $(1982,127)$ ei löydä enää grundtvigilaisia ajatuksia julkilausuttuna tavoitteena 80-luvun kansanopistosta: "aikuiskoulutuksen uudistus... on suuntaamassa kansanopiston kasvatusajatusta perinteisestä grundtvigilaisesta sivistysideasta teknisempään, kontrolloidumpaan ja hyötytavoitteisempaan koulutusnäkemykseen". Samoin Suomessakin hyvään vauhtiin päässyt opintokerho alkoi näivettyä. Sen hengiltäottoa pohdittiin vakavasti 1990-luvun alussa, mutta kukaan ei hennonut sitä tehdä. Opintokerho kituu ilman kehittämisponnistuksia lähinnä eläkeläistoiminnassa. Jotkut opintokeskukset ovat tosin julkaisseet opintokerhoa kehittäviä aineistoja ja alalla on valmiutta soveltaa työmuotoa myös uusiin tehtäviin (Rantanen 1999, 142-154). 


\section{VAPAA}

$\mathrm{E}$ dellisestä näkyy, miten vapaa kansansivistysyö modernisoitiin kovalla kädellä 1960-luvulta alkaen osaksi nousevaa aikuiskoulutuksen aaltoa. ${ }^{4}$ Se kadotti perinnölleen ominaisen sosiaalisen, menetti oleelliset ominaispiirteensä ja jäi organisatoriseksi termiksi tavalla, jonka Huuhka $(1960,17)$ professori Urpo Harvaan vedoten paljonpuhuvasti ennakoi: "... jos taiteentuntija museon toimesta esittelee 'viikon taideteoksen', se ei ole vapaata kansansivistystyötä, mutta jos hän pitää saman esityksen työväenopiston järjestämänä, se on vapaata kansansivistystyötä”. Huuhkan mukaan Harva tosin katsoi kansansivistysjärjestöjen eduksi sen, ettei "niiden järjestämä opinto- ja kasvatustoiminta keskity vain suppealle alueelle, vaan tarkoittaa koko ihmisen kasvattamista”. Mutta lievennys oli enää heikko. Huuhkalle keskeinen käsite oli aikuiskasvatus, jota kansansivistyksen instituutiot tekivät siinä missä muutkin.

Vain vapaus jäi elämään. Vapaa sivistystyö on näihin päiviin saanut itse etsiä tehtävänsä. Toinen asia on, mitä mahdollisuuksia tällä on ollut onnistua, kun vapaan kansansivistystyön käsitteellinen sisältö tyhjennettiin, opetusministeriö luopui alan kehittämisestä 1970-luvulla kahdeksi vuosikymmeneksi, alan opetus, tutkimus ja oma auskultointi lopetettiin, vain ammatillista koulutusta arvostettiin, aikuiskasvatusta pääaineenakin lukeneet saattoivat olla tietämättömiä vapaasta sivistystyöstä (professori Jukka Tuomiston ja dosentti Timo Toiviaisen oppilaita lukuun ottamatta) ja suhteellisen pienet instituutiot jäivät kamppailemaan olemassaolostaan. Ongelmallista suhdetta vapauteen kuvaa Kansanopistoyhdistyksen satavuotisjuhlajulkaisun nimi Vapauden vankina (1989). Vaihtoehdoksi jäi lähinnä yleisen aikuiskasvatusjärjestelmän aukkojen paikkaaminen; tässä avoimen yliopiston suomalainen versio on ollut tärkeä. Että vapaa sivistystyö on näissäkin oloissa selviytynyt, on itsessään menestystarina ja osoitus "katajaisen" kansamme snellmanilaisesta sivistystahdosta: taipuu muttei taitu.

Vapaan kansansivistystyön edelleen vahva insti- tuutiopohja olisi hyvä lähtökohta kansansivistyksen itsenäisen tehtävän uudelle tulemiselle. Onko sellaista näköpiirissä? Onko kansansivistyksen traditiolla muuta kuin historiallinen mielenkiinto? Onko tradition elpymiseen aitoa tarvetta? Vastausta voi etsiä siitä elinikäiseen oppimiseen johtaneesta kehitysprosessista, joka alkoi OECD:n koulutusajattelussa 1990-luvun alussa ja perustui huolellisiin analyyseihin myöhäisteollisen yhteiskunnan luonteesta.

\section{ELINIKÄINEN OPPIMINEN}

E linikäisen oppimisen varhaiset OECD-dokumentit korostivat vapaan sivistystyön pohjoismaisen tradition hengessä oppimisen itseisarvoisuutta välinearvon ohella, oppimismahdollisuuksien saattamista kaikkien ulottuville sekä formaalin rinnalla nonformaalia ja metodisesti monimuotoista oppimista. Niin ikään demokratian ongelmat, yhteisöjen toimivuus ja sosiaalinen koheesio nousivat esille. (OECD, 1995)

Vaikutteet ovat ilmeisiä, kun OECD:n herätteestä Suomeen perustettu elinikäisen oppimisen komitea listasi Oppimisen ilo -mietinnössään $(1997,29)$ tavoitteitaan. Niitä olivat persoonallisen kehityksen tukeminen, demokraattisten arvojen vahvistaminen, toimivien yhteisöjen ja sosiaalisen yhteenkuuluvuuden ylläpitäminen sekä innovaatiot, tuottavuus ja kansallinen kilpailukyky. Jo komitean keskusteluissa todettiin, että elinikäinen oppiminen antaa vapaalle sivistystyölle sen perinteisessä merkityksessä mahdollisuuden kirjoittaa itsensä uudelleen sisään koulutuspolitiikkaan. ${ }^{5}$ Tavoitteet konkretisoituivat painotuksissa, joilla komitea käsitteli oppimisen perustaa ja toisaalta kansalaisjärjestöjä. Siitä lähtien vapaa sivistystyö on taas ollut mukana keskeisissä koulutuspoliittisissa dokumenteissa. Parlamentaarinen aikuiskoulutustyöryhmä (2002) esittää sen rahoituksen oleellista lisäämistä.

Euroopan Unionissa alettiin puhua elinikäisestä oppimisesta heti, kun koulutuskysymykset tulivat Maastrichtin sopimuksessa Unionin toimivaltaan. Sen keskustelua hallitsi kuitenkin kapea taloudellinen painotus koko 1990-luvun ajan. Esimerkiksi valkoiset kirjat vuosina 1993 ja 1995 
korostivat yksinomaan kilpailukykyä, kasvua ja työllistämistä. Vuosituhannen vaihteessa ajattelu muuttui kuitenkin perusluontoisesti, minkä näkyvä esimerkki on vuoden 2000 elinikäisen oppimisen muistio (Bron, 2001, 138). Se nosti aktiivisen kansalaisuuden työllistettävyyden rinnalle toiminnan yhtä tärkeäksi tavoitteeksi. ${ }^{6}$ Niin ikään se korosti nonformaalia oppimista ja kansalaisjärjestöjä oppimisfoorumeina.

Uusin komission julistus (2001) on vielä laajaalaisempi ja kansansivistyksen pohjoismaisen tradition kannalta erityisen kiinnostava. Elinikäisen oppimisen tavoitteet on koottu neljään ryhmään. Persoonallinen kehittyminen tai 'toteuttaminen' (personal fulfilment) viittaa perustavaan sivistysajatukseen ihmisen sisäisistä potentiaaleista, joiden kehittäminen on itsessään arvokasta ja samalla luovuuden ja aloitekyvyn lähde. Aktiivinen kansalaisuus (active citizenship) paikalliskansalaisesta aina maailmankansalaiseksi on korostuva tavoite taustanaan niin yhteisöelämän kuin demokratian ongelmat ja kansalaisyhteiskunnan rooli nopean muutoksen yhteiskunnassa. Sosiaalinen eheyttäminen (social inclusion) kannustaa käyttämään oppimista tasa-arvon lisääjänä ja syrjäytymisen estäjänä; nythän aikuiskasvatus lisää eriarvoisuutta siitä yksinkertaisesta syystä, että sen palveluita käyttävät eniten parhaiten koulutetut. Työllistettävyys ja muutokseen sopeutuminen (employability, adaptability) ovat välttämättömyyksiä nopeasti muuttuvassa työelämässä.

Tällaisten tavoitteiden taustaa vasten pohjoismaisen vapaan kansansivistystyön sivistyksellinen ja yhteisöllinen perinne osoittautuu aarreaitaksi. Sillä voi odottaa olevan paljon annettavaa eurooppalaiseen keskusteluun. Kadotetun tradition elpymisen prosessi onkin alkanut monissa alan oppilaitoksissa (ks. esim. Koivunen, 2001). Kysymys on mittavasta kehityshaasteesta, johon opetusministeriön rahoittama vapaan sivistystyön henkilöstön kehittämisohjelma VSOP antaa välineitä.

Vapaa sivistystyö voi tehdä moniakin tehtäviä, mutta sen omimpia alueita on edelleen kaksi. Vapaan sivistystyön suuri etuoikeus on järjestää persoonallisuutta monipuolisesti kehittäviä opintoja - mukaan lukien käden taidot - silloinkin kun niillä ei ole suoraa yhteyttä ammatillisiin kompetensseihin. Vapaa sivistystyö on osa kansalaisyhteiskuntaa, luo oppivia yhteisöjä ja rakentaa sosiaalista pääomaa sen lisäksi, että se työskentelee aktiivisen kansalaisuuden hyväksi yhdessä yhteisöjen ja oppivina organisaatioina toimivien yhdistysten kanssa. Näissä tehtävissä sen omin didaktinen lähestymistapa on vuorovaikutus ja yhdessä oppiminen. Yhteisöllinen oppiminen saattaa olla monelle ainoa tie tietoyhteiskunnassa tarvittavaan oppimisen perustaan, myös yleissivistäviin tutkintoihin.

\section{Viitteet}

1 Nummisen komitea ehdotti lakia vapaatavoittei sista opinnoista. Ajatusta ei juurikaan kehitetty pidemmälle. Sivistysjärjestöt asettautuivat jyrkkään puolustukseen. Lakiuudistusta käsitellyt parlamentaarinen työryhmä päätti, että työmuotojen aiemmat omat lait yhdistetään laiksi vapaasta sivistystyöstä. Perheeseen liitettiin kesäyliopistot ja liikunnan oppilaitokset. Lain tarkoituspykälä juurtuu hyvin kansansivistyksen pohjoismaiseen traditioon, sillä edistettävänä ovat persoonallisuuden monipuolisuus, kyky toimia yhteisöissä sekä tasa-arvo, kansanvalta ja moniarvoisuus suomalaisessa yhteiskunnassa.

Korsgaard $(2001,21)$ tekee tämän jaon vertailLessaan Saksaa ja Tanskaa. Kun saksalaiset oppineet painottivat voimakkaasti valtiota saksalaisen kansakunnan ytimenä, piti Grundtvig Tanskassa kansaa kansakunnan ytimenä. Edellinen johti katastrofeihin, jälkimmäinen kansanopistoon, osuustoimintaan sekä keskustelulle ja kompromisseille rakentuvaan parlamentarismiin, joka kunnioitti myös vähemmistöjä.

3 Tähän laajempaan opintokerhon merkitykseen 3 viittasi amerikkalais-ruotsalainen demokratiatutkija Michele Micheletti mieleenpainuvasti eräässä 1990-luvun alun Pohjoismaisen Aikuiskasvatusliiton seminaarissa. Hän katseli Ruotsin opintokerhon osallistumislukuja esittävää kalvoa ja sanoi, että amerikkalaisin silmin nämä kyllä tekevät vaikutuksen. "Eikä minua kiinnosta yhtään, mitä he siellä tekevät", hän sanoi. Osallistuminen opinnollisiin yhteisöihin on demokratiatutkijan mukaan jo sellaisenaan arvokasta.

$\triangle$ Auskultoin kansanopiston opettajaksi 70-luvun lopulla. Meidät opetettiin käyttämään silloista luokkaopetuksen yleistä didaktiikkaa. En muista opinnoista muuta johdatusta kansansivistysperintöön kuin sen, että Grundtvigin nimi piti oppia kirjoittamaan 
oikein ja että silloin peräsimessä ollut Kosti Huuhka korosti vapautta. Opimme, että vapaa sivistystyö etsii itse tehtävänsä eikä sitä pidä mennä viranomaisilta kyselemään.

5 Käsitys perustuu omiin muistikuviini komitean $\mathcal{~ t y o ̈ r y h m a ̈ n ~ k e s k u s t e l u i s t a ~ k e s a ̈ l t a ̈ ~ 1 9 9 7 , ~ j o l l o i n ~ k o - ~}$ mitean varapuheenjohtaja, kansliapäällikkö Vilho Hirvi totesi uuden tulemisen mahdollisuuden ääneen.

6 Kansansivistystyöllä on ollut vaikeuksia ilmaista itseään englanniksi, aina nimeä myöten. Tavallisin käännös liberal adult education samoin kuin joskus käytetty popular adult education antavat aiheen toistuville väärinkäsityksille. Nonformal adult education ei sekään ole yksiselitteinen. Mutta vapaan kansansivistystyön tavoitetta voi tuskin millään kielellä ilmaista paremmin kuin A Memorandum of Lifelong Learning ilmaisee oman tavoitteensa: "Our common aim is a Europe, where everybody can develop their potential to the fullest, feel that they can contribute and they belong."

\section{Kirjallisuus}

ALANEN, Aulis (1969). Edistävä ja viihdyttävä opintokerhotoiminta. Acta Universitatis Tamperensis. Ser A. Vol. 29. Myllykoski.

ALANEN, Aulis (1986). Sivistysjärjestöjen tehtäväkuvan muuttuminen. Tampereen yliopisto. Aikuisja nuorisokasvatuksen laitoksen julkaisuja. 23/ 1986.

ALANEN, Aulis (1992). Suomen aikuiskasvatuksen organisaatiomuodot. Tampereen yliopisto. Kasvatustieteen laitos. B7

BERGSTEDT, Bosse (1998). Den livsupplysande texten. En läsning av N F S Grundtvigs pedagogiska skrifter.

BRON, AGNIESZKA (2001). Learning for Active Citizenship. Kirjassa Korsgaard, O. - Walters, S. Andersen, R. 2001. Learning for Democratic Citizenship. Association for World Education and the Danish University of Education.

EDWARDS, Michael (1999). Enthusiasts, Tacticians and Sceptics: The World Bank, Civil Society and Social Capital. http://www.worldbank.org/poverty/scapital/library/edwards/pdt

EU 2000. European Commission. The Memorandum of Lifelong Learning. Brussels.

EU 2001. European Commission. Making a European Area of Lifelong Learning a Reality. Brussels.

FAGERLUND, Sten-Erik (1984). Takolanderin opisto ja meidän opistomme. Kirjassa Tiensuu, K. ja Niemelä, S. (toim.) 1984. Kansanopisto elää. Suomen kansanopistoyhdistys ry.

FBR 1998. Folkbildningsrådets sammanfattande utvärderingsrapport 1993-1997.

GUSTAVSSON, Berndt (1996). Bildning i vår tid. Wahlström\&Widstrand.

HUUHKA, Kosti (1960). Vapaa kansansivistystyö ja aikuiskasvatus. Artikkeli kirjassa Vapaa kansansivistystyö VIII. Kansanvalistusseura. Kansansivistysopillinen yhdistys. Helsinki.

JOHANSSON, Tore (1990). Vägvalet. En bok om folkbildning i brytningstid. Studieförbundet Vuxenskolan.
KOIVUNEN, Ulla (toim.2001). Kokonaisuutta etsimässä. På jakt efter helheten. Kansanvalistusseura

KORSGAARD, Ove (1997). Kampen om lyset. Dansk voksenoplysning gennem 500 år. Gyldendahl.

KORSGAARD, Ove (1999). Kundskap-kaploebet. Uddannelse i vidensamfundet. Gyldendahl.

KORSGAARD, Ove (2001). Kampen om folket. Kirjassa Korsgaard, O. (red.) 2001. Poetisk demokrati. Om personlig dannelse og samfundsdannelse. Gads Forlag.

KUISMA, J. ja Niemelä, S. (toim.1983). Santeri Alkio. Ituja. Kirjayhtymä.

LEISTEVUO, Arto (1998). Sosiaaliset motiivit ja sosiaalinen toiminta aikuisopiskelussa. Acta Universitatis Tamperensis 584 .

OECD (1995). Towards lifelong learning for all. Background report.

Oppimisen ilo. Kansallisen elinikäisen oppimisen strategia. Komiteanmietintö 1997:14. Opetusministeriö.

PUTNAM, Robert D. (1994). Making Democracy Work. Civic traditions in Modern Italy. Princeton University Press.

PUTNAM, Robert D. (2000). Bowling alone. The Collapse and Revival of American Community. Simon\&Schuster.

RANTANEN, Pertti (1999). Uutta sivistystyötä syrjäytymistä vastaan. Kirjassa Sallila, P. ja Niemelä, S. (toim.) 1999. Sivistystyö osaamisyhteiskunnassa. Aikuiskasvatuksen 40. vuosikirja.

SILJANDER, Pauli (1982). N. F. S. Grundtvigin sivistyskäsitys ja kansanopiston tehtävä. Oulun yliopiston kasvatustieteen laitoksen tutkimuksia 11/ 1882 .

SNELLMAN, J. V. (1991). Sivistys ja yleishenki. Kirjassa Aaltonen, R. ja Tuomisto, J. (toim.). Valistus, sivistys, kasvatus. Kansanvalistuksesta aikuiskasvatukseen. Vapaan sivistystyön XXXII vuosikirja. Kansanvalistusseura ja Aikuiskasvatuksen tutkimusseura.

TOIVIAINEN, Timo (1998). An overview of Finnish Liberal Adult Education on the Edge of the 21st Century. Kirjassa Toiviainen, T. (ed.) 1998. Responding to the Challenges of a Changing World: An Overview of Liberal Adult Education in Finland. Finnish Adult Education Association.

VIRTANEN, Sari (toim.1989). Vapauden vankina. Sata vuotta kansanopistotoimintaa Suomessa. Suomen kansanopistoyhdistys ry.

Artikkeli saapui toimitukseen 20.1.2002. Se hyväksyttiin julkaistavaksi toimituskunnan kokouksessa 11.3.2002. 